\title{
A PHONOLOGICAL ANALYSIS ON MADURESE ENGLISH TEACHER'S PRONUNCIATION IN READING AN ENGLISH TEXT
}

\author{
Tiyas Saputri \\ Email: tiyass@unusa.ac.id \\ Nahdlatul Ulama University, Surabaya
}

\begin{abstract}
This study concerns on a phonological analysis on Madurese English teacher's pronunciation in reading an English text. The writer identified kinds of oscillographic pronunciation made by Madurese English teachers in reading an English text, the differences of oscillographic pronunciation between Madurese English teachers and that of the English native speaker in reading an English text and how Madurese language characteristics influences Madurese English teachers' pronunciation. In the process of data collection, she used descriptive qualitative. She observed and recorded the Madurese English teachers'pronunciation by using MP4 then analysed it by using Praat program version 4027. Then, she found that in reading the English text entitled 'insomnia', the oscillographic pronunciation of Subject 2 and Subject 3 when it is compared to subject 1 is different and makes different meaning, but for some words, it is slightly different but it does not make different meaning. Furthermore, it is found that Madurese language characteristics influence Subject 2 and Subject 3 in reading the English text. Therefore, in reading it, they made some sound changes: vowel, consonant and diphthong. The sound changes are: 1). the vowel changes: /I/_i/;/ə/, /i/_e/;/ə/, /3/_//, /a/_/o/;/っ/;/a/, /e/_il;/ə/;/I/, /ə/_il/, 2). the consonant changes: /z/_/s/, /t $\int / / t /, / v / \_/$,

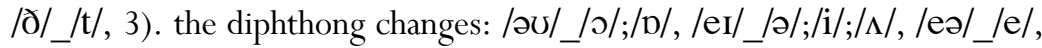
/aI/_i/, /av/_/u/;/o/. In reading it, it is found that subject 2 and subject 3 also made deletion and addition. It is, thus, concluded that the pronunciation of subject 2 and subject 3 are unintelligible because they often mispronounce which can make their students do not understand their saying.
\end{abstract}

Keywords: Oscillographic Pronunciation, Madurese English Characteristics

\section{INTRODUCTION}

In teaching English, English teachers have to use English with correct pronunciation. It is important for them to have correct 
pronunciation of English as they are English teachers who should be good models for their students in learning English. In fact, there are some of English teachers in Indonesia that still have problems of English pronunciation. They are influenced by their mother tongue. It can be seen through two Madurese English teachers. They have problems in pronouncing the English words. This phenomenon occurs because of the interference of their mother tongue (especially local or regional languages) that is Madurese Language. The interference of the mother tongue has come into main consideration since language transfer plays an important role. In this case, the English teachers have to face that one factor which provides difficulty in acquiring English language as their second or foreign language is the teachers' first language (L1). In producing speech, they use L1 pattern or rule that leads to inappropriate form in the target language. The use of L1 pattern in the production of L2 is known as 'negative transfer' or 'interference' (Richards, Platt \& Weber, 1992: 160). Interference mostly occurs because their knowledge about L2 is incomplete (Kormos, 2006: 26). Therefore, in producing speech of L2, it is important to master the knowledge about it. Seeing the phenomena above of the two Madurese English teachers in making mispronunciation due to the difficulties provided by English pronunciation and the influence of their first language, the writer is eager to learn more about this problem.

According to Odden (2006: 2), pronunciation is regarded as the primary part of the structure of a word. The main reason for that idea comes from the knowledge that one of the important features of the structure of a word is how that word is pronounced. For that reason, Odden (2006: 2) relates pronunciation to the foundation areas of linguistics that deals with scientific study of the language structure, that is, phonology. Phonology deals with the linguistic patterning of sounds in human languages, while phonetics is the study of the aspects of speech (Robins, 1989: 77). Phonetics is a science which focuses on the characteristic of human sound-making; especially sounds used in speech, and provide methods for their description, classification, and transcription (Crystal, 1997: 289). In other words, Brown (2005: 3) emphasizes on the accuracy of speaking due to the fact that even if someone is fluent in conveying what he / she has in mind, it does not 
mean that others will directly understand what he / she is saying. Since the accuracy in pronouncing words is essential, English teachers should pay more attention on the way they articulate foreign words and master pronunciation of a language they are teaching.

According to Jones (1987: 25-26) English consonants can be classified based on the organs which articulate them (the place of articulation). Based on the place of articulation, consonants can be distinguished into seven main classes as the following.

Table 1. English Consonants Based on Manner of Articulation and Place of Articulation (Jones, 1987: 26)

\begin{tabular}{|c|c|c|c|c|c|c|c|c|}
\hline & \multicolumn{2}{|c|}{ Labial } & \multirow[b]{2}{*}{$\begin{array}{c}\text { Dent } \\
\text { al }\end{array}$} & \multirow[b]{2}{*}{$\begin{array}{c}\text { Alveo } \\
\text { lar }\end{array}$} & \multirow[b]{2}{*}{$\begin{array}{l}\text { Palato- } \\
\text { alveolar }\end{array}$} & \multirow[b]{2}{*}{$\begin{array}{c}\text { Palat } \\
\text { al }\end{array}$} & \multirow[b]{2}{*}{ Velar } & \multirow{2}{*}{$\begin{array}{c}\text { Glot } \\
\text { tal }\end{array}$} \\
\hline & Bilabia & Labiode & & & & & & \\
\hline $\begin{array}{l}\text { Plosiv } \\
\mathrm{e}\end{array}$ & $\mathrm{p} \quad \mathrm{b}$ & & & $\mathrm{t}^{\mathrm{d}}$ & & & $\begin{array}{l}\mathrm{k} \\
\mathrm{g}\end{array}$ & $?$ \\
\hline $\begin{array}{l}\text { Affrica } \\
\text { te }\end{array}$ & & & & & $\mathrm{t} \int \quad \mathrm{d} 3$ & & & \\
\hline Nasal & $\mathrm{m}$ & & & $\mathrm{n}$ & & & $\eta$ & \\
\hline Lateral & & & & 1 & & & (1) & \\
\hline Rolled & & & & $\begin{array}{l}\text { [ } \\
\mathrm{r}]\end{array}$ & & & & \\
\hline $\begin{array}{l}\text { Flappe } \\
\text { d }\end{array}$ & & & & $\begin{array}{c}\text { [ } \\
\mathrm{r}]\end{array}$ & & & & \\
\hline $\begin{array}{l}\text { Fricati } \\
\text { ve }\end{array}$ & & f $\quad v$ & $\theta \quad \partial$ & $\begin{array}{ll}\mathrm{s} & \\
\mathrm{z} & \mathrm{r}\end{array}$ & 3 & & & h \\
\hline $\begin{array}{l}\text { Semi- } \\
\text { vowel }\end{array}$ & W & & & & & $\mathrm{j}$ & $\begin{array}{l}\text { ( } \\
\text { w) }\end{array}$ & \\
\hline
\end{tabular}

English vowels are conventionally differentiated from consonants by reference to their articulation. Whereas with consonants 
the speech organs restrict the air flow in some manner, vowels are produced without any such restriction.

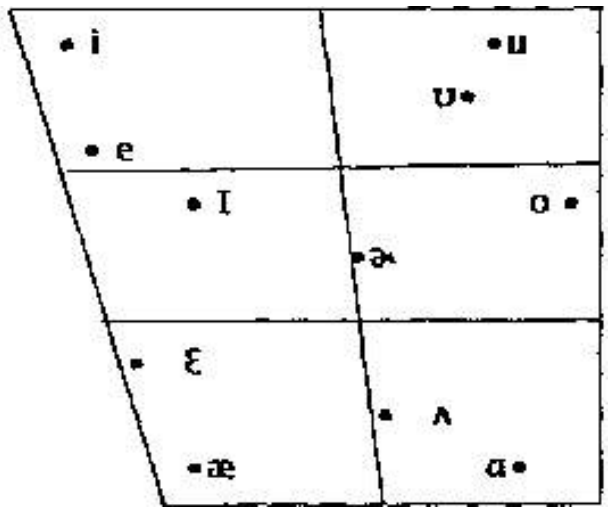

(Source: Handbook of the International Phonetic Association; A Guide to The Use of the International Phonetic Alphabet, 2000, Cambridge.

Cambridge University Press. p.42)

\section{Figure 1. American English Monophthongs}

English has two kinds of diphthongs, they are rising and falling diphthongs. A diphthong consists of a preliminary on-glide followed by a syllabic vowel is called rising because the intensity of stress increases as the syllable goes on. On the other hand, a diphthong consists of the syllabic vowel followed by an off-glide is called falling because the intensity of stress decreases. Falling diphthongs can be classified into three main groups according to the nature of the off-glide. These groups are: diphthongs with a mid or high front off-glide, diphthongs with a mid or high back off-glide, and diphthongs with a mid central off-glide.

The diphthongs with a mid or high front off-glide have as their syllabic element any one of the vowels except / i/ and / $\mathrm{u} /$. They have as their off-glide one of the mid or high front vowels $/ \mathrm{i}, \mathrm{I}, \varepsilon, \leftrightarrow /$. The off-glide is always higher than the syllabic vowel. Thus, the movement from the syllabic to off-glide is upward and forward, so that these diphthongs are also called fronting diphthong. The example of 
fronting diphthongs are time $/ \tau \alpha \iota \mu /$, like $/ \lambda \alpha \iota \kappa /$, rice $/ \rho \alpha \iota \sigma /$, base $/ \beta \leftrightarrow \mathrm{I} \sigma /$, boy $/ \beta\lrcorner \mathfrak{l} /$, coy $/ \chi\lrcorner \mathfrak{\imath} /$.

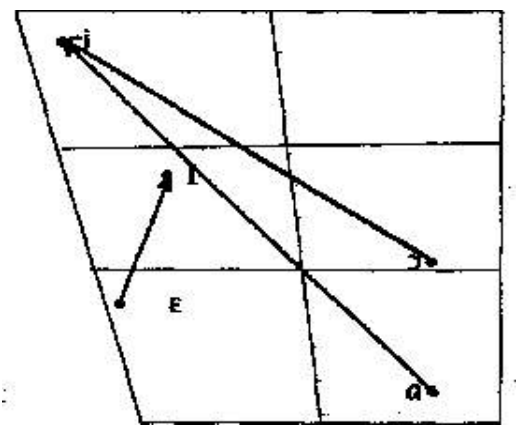

Figure 2. English Fronting Diphthong

(Source: Francis, W. Nelson. 1958. The Structures of American

English. New York: The Ronal Press Company. p 108)

The diphthongs with a mid or high back off-glide or retracting diphthongs have as their syllabic vowel one of the same vowels as in the fronting diphthongs, but the off-glide is one of the higher back vowels $/ \mathrm{U}, \leftarrow, \downarrow, \mathrm{O} /$. The movement from syllabic to off-glide is thus upward and back.

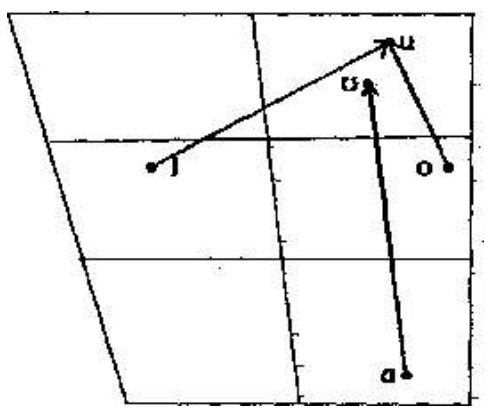

Figure 3. English Retracting Diphthong

(Source: Francis, W. Nelson. 1958. The Structures of American English. New York: The Ronal Press Company. p 109) 
The diphthongs with a mid or high central off-glide, the centering diphthongs, may have as syllabic any of the vowels except $/ \varepsilon, 3, ə, \mid /$. As off-glide they may have $/ \curvearrowright, \mid /$.

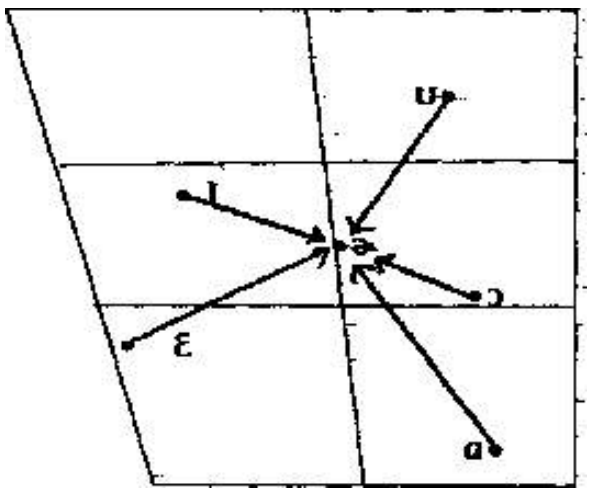

\section{Figure 4. English Centering Diphthong}

(Source: Francis, W. Nelson. 1958. The Structures of American English.

New York: The Ronal Press Company. p 110)

Madurese consonants are classified according to the following criteria:

a. the obstruction of the air stream from the lungs,

b. the vocal organs used to produce the contoids forming points of articulation that may disturb the air stream from the lungs at the articulation,

c. the vibration of the vocal cords,

d. the aspiration or no aspiration.

Based on the existence of some obstruction of the air stream from the lungs, there are some following consonants: plosives, affricates, nasals, laterals, fricatives, trills, geminate, and semi-vowels. In line with points of articulation, there are bilabials, apico-alveolar, retroflex, lamino-alveolar, dorsovelar, pharyngeal, and glottal. Next, there are voiced and voiceless consonants. Finally, there are also aspirated and unaspirated consonants. However, Madurese has twentynine contoids or the allophones of the consonants, they are $/ \mathrm{p} /, / \mathrm{b} /$, $/ \mathrm{bh} /, / \mathrm{t} /, / \mathrm{dh} /, / \mathrm{t} /, / \mathrm{d} /, / \mathrm{d} /, / \mathrm{k} /, / \mathrm{g} /, / \mathrm{gh} /, / \mathrm{l} /, / \mathrm{s} /, / \mathrm{c} /$, $/ \mathrm{j} /, / \mathrm{jh} /, / \mathrm{m} /, / \mathrm{n} /, / \tilde{\mathrm{n}} /, / \mathrm{y} /, / \mathrm{l} /, / \mathrm{r} /, / \mathrm{y} /, / \mathrm{w} /, / \mathrm{dh} /, / \mathrm{f} /, / \mathrm{h} /$, /v/, / z/ (Pawitra, 2008: xxviii). The Madurese consonants chart can 
be seen below (p.8), but it will be clearly shown with the examples in appendix.

Madurese has ten vowels, they are $/ \mathrm{i} /, / \varepsilon /, / \mathrm{a} /, / \mathfrak{v} /, / \mathrm{u} /$, /ə/, /ひ/, /っ/, /o/, /I/ (Pawitra, 2008: xxviii). The vowels, like English vowels, arrange them according to their place of articulation in the mouth. Front, central, back, high, mid, and low represent the position of the tongue in the mouth. Rounded and unrounded refer to the shape of the lips. Then, close and open refer to relative openings of the jaw. The Madurese vowels chart can be seen below. The Madurese vowels table will be shown with the examples in appendix.

Table 2. Madurese Consonants Chart (Sofyan, 2008:44)

\begin{tabular}{|c|c|c|c|c|c|c|c|c|c|c|c|}
\hline $\begin{array}{l}\text { Place of } \\
\text { articula }\end{array}$ & & & & & $\begin{array}{l}\text { Dental } \\
\text { ar }\end{array}$ & alveol & & & & & Glottal \\
\hline $\begin{array}{l}\text { tion } \\
\text { Manner } \\
\text { of } \\
\text { articulation }\end{array}$ & 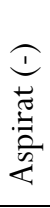 & 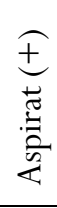 & 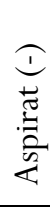 & 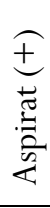 & 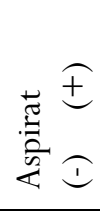 & 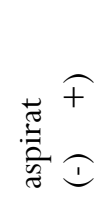 & 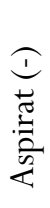 & \begin{tabular}{l} 
I \\
$\stackrel{0}{0}$ \\
$\stackrel{0}{0}$ \\
\multirow{2}{*}{}
\end{tabular} & 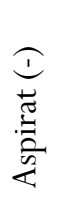 & 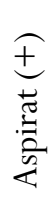 & \\
\hline $\begin{array}{l}\text { Plosive } \\
(-)\end{array}$ & $\mathrm{p}$ & & & & $\mathrm{t}$ & $\mathrm{t}$ & & & $\mathrm{k}$ & & $?$ \\
\hline$(+)$ & $\mathrm{b}$ & $\mathrm{b}^{\mathrm{h}}$ & & & $\mathrm{d} \quad \mathrm{d}^{\mathrm{h}}$ & $d \underset{h}{d}$ & & & $\mathrm{~g}$ & $\mathrm{~g}^{\mathrm{h}}$ & \\
\hline $\begin{array}{l}\text { Fricative (-) } \\
(+)\end{array}$ & & & $f$ & $\mathrm{~V}$ & & $\begin{array}{l}\mathrm{S} \\
\mathrm{Z} \\
\end{array}$ & & & & & $\mathrm{h}$ \\
\hline Nasal & $\mathrm{m}$ & & & & & $\mathrm{n}$ & $\eta$ & & $\eta$ & & \\
\hline $\begin{array}{l}\text { Affricate (-) } \\
(+)\end{array}$ & & & & & & & $\begin{array}{l}\mathrm{c} \\
\mathrm{j}\end{array}$ & $\mathrm{j}^{\mathrm{h}}$ & & & \\
\hline Trill & & & & & & $r$ & & & & & \\
\hline Lateral & & & & & & 1 & & & & & \\
\hline Semivowel & $\mathrm{W}$ & & & & & $\mathrm{y}$ & & & & & \\
\hline
\end{tabular}


The Vocoid Map Based on The Position of The Tongue

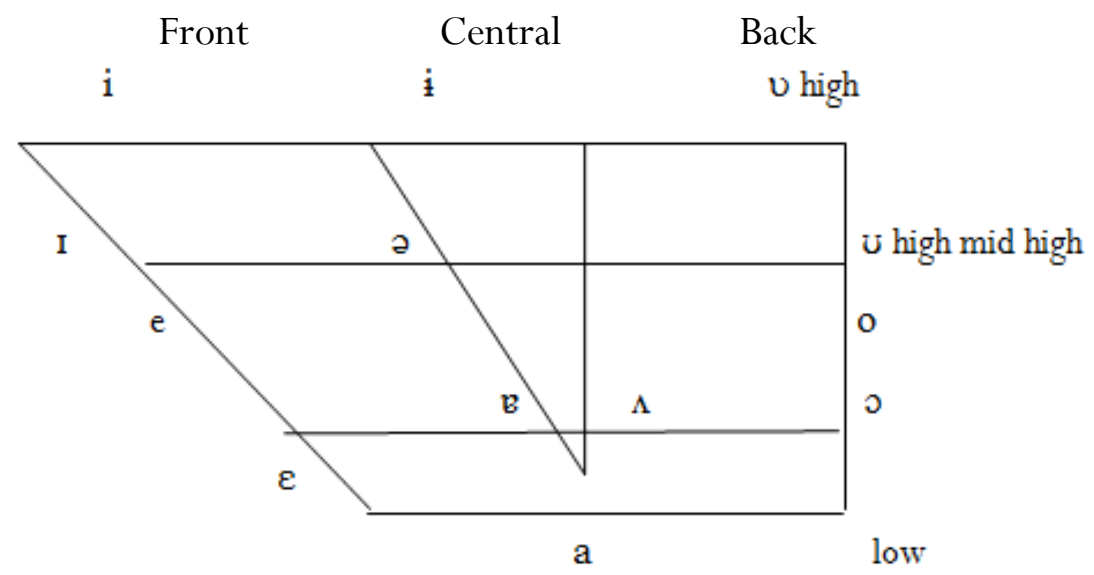

\section{Figure 5. Madurese Vowels Chart (c.f. Budi in Wahyuningrum, 2006)}

Madurese has three diphthongs, they are /oy/, /ay/, and /uy/ (Balai Bahasa, 2003: 4). The distribution of diphthongs /oy/ and /ay/ is in the final and medial, whereas diphthong /uy/ is in the final. Diphthong/oy/ can be found in the word [tamoy] 'guest', diphthong /ay/ in [ketay] 'weak', diphthong /uy/ in [anghuy] 'wear. The Madurese diphthongs table with the examples is shown in appendix. According to Wahyuningrum (2006, p. 75) in her thesis finding, the characteristics of Madurese language are:

a. The distribution of consonant [d] in Madurese language never occurs in the final

b. There is no phoneme [z] in Madurese language, it is substituted by [s]

c. In producing sound [v], it is referred to [f]

d. [ $\left.\int\right]$ and [3] only happened finally or medially.

e. $[\theta]$ was often transferred to $[t]$

f. In producing sound diphthong [əひ], it is referred to [o]

g. In producing sound diphthong [æ], it is referred to $[\varepsilon]$

These characteristics of Madurese language can influence the Madurese English teachers in pronouncing the English words. 
In reading the English text, subject 2 and 3 is influenced by their accent. An accent is the systematic use of the same pronunciation as a whole by a particular group of people. It is restricted to the description of aspects of pronunciation which identifies where an individual speaker is from. When individuals from two different speech communities meet in a conversation, they are able to identify their differences by their accents. However, some speakers may have distinct or easily recognized type of accent, while others do not. Yet, every language user speaks with an accent. While observing this problem deeper, the writer intends to observe the mispronunciation done by two Madurese English teachers. The main reason why the writer chooses them firstly arises from the fact that throughout her study, the writer notices that when they speak English, they produce inappropriate form in pronunciation and their accent is Madurese. To prove this, the writer asks them to read an English text and compares their pronunciation with an English native speaker's.

\section{RESEARCH METHOD}

In this research, the writer uses a qualitative research approach. The reason is that this approach can help the writer in collecting and analyzing oscillographic pronunciation made by Madurese English teachers in reading English and compared to the native speaker. The subjects of the research are two Madurese English teachers (subject 2 and subject 3) and a native speaker (subject 1). Moreover, using this approach, the writer can know the differences of oscillographic pronunciation between Madurese English teachers and the native speaker in reading English text and describe how Madurese language characteristics influence their English pronunciation. Therefore, the writer does observation and recording of Madurese English teachers compared to the native speaker in reading an English text. The English text read is the text that they use to teach English in the class with the same grade. In recording the data, the writer uses MP4 recorder to record the pronunciation produced by the respondents. The pronunciation produced is transcribed phonetically and analyzed by using praat program 4027. Finally, the writer then uses a descriptive analysis method. It means that after all of the collected data 
are analyzed qualitatively, the results of the analysis will then be interpreted descriptively and compared the oscillographic pronunciation among them. Furthermore, this research is conducted based on the research design as follow (p.12):

After collecting the data, the writer process the data by using phonetic analysis, which is structurally performed to refer to articulatory phonetics that yield to segmentation of the speech sounds into smaller elements such as vowel, consonant or diphthong sounds based on the sound changes. Next, she displays the data in the form of tables and oscillograms in order to classify the data. The data is classified based on the English pronunciation produced by Madurese English teachers and the English native speaker in reading the same English text. Then, the oscillographic pronunciation and phonetic transcription of Madurese English teachers and that of the English native speaker are compared. After that, the she shows the characteristics of sound changes made by Madurese English teachers and what phonological process influences the sound changes. The tables are shown in appendix. After displaying the data, she interprets the data in order to get the answer of the research problems. At last, she makes a conclusion about kinds of oscillographic pronunciation made by Madurese English teachers in reading English text and compared to the English native speaker and the differences of it, and how Madurese language characteristics influence Madurese English teacher's pronunciation.

\section{FINDINGS}

These are examples of different oscillographic pronunciation among 3 subjects in reading "Insomnia" English text.

\section{Figure 7. The Comparation of Oscillographic Pronunciation of 'cause'}

Subject 1 (Native Speaker) 
A Phonological Analysis

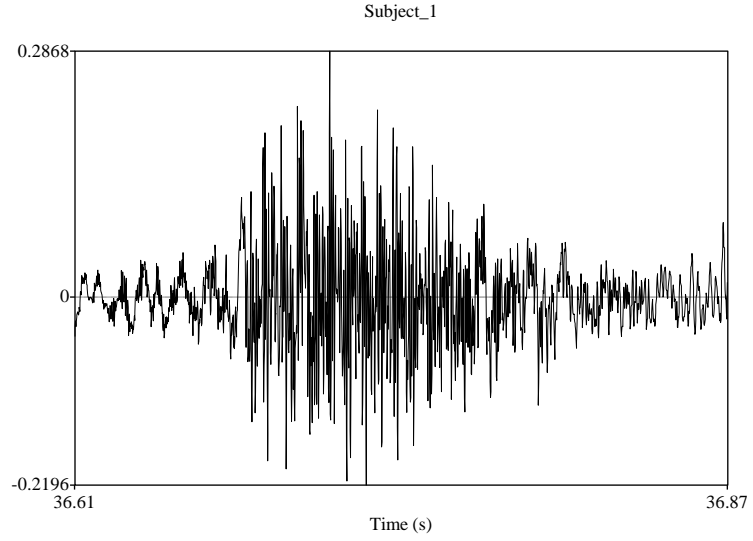

[kaz]

Subject 2 (Madurese English Teacher 1) Subject_2

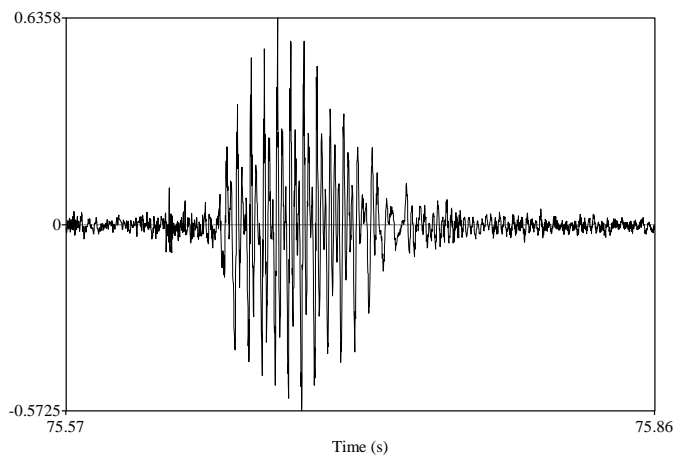

[keIs]

Subject 3 (Madurese English Teacher 2) Subject_3

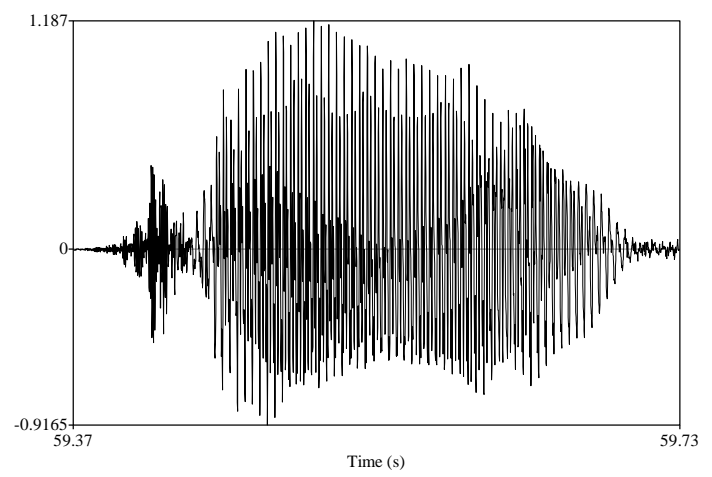


[kos]

Based on those three oscillograms above, we can see that subject 1 pronounces 'cause' with frequency -0,2196-0,2868 and time 0,16 second. When she pronounces 'cause' the harmonics of amplitude are weak in the beginning then strong, and after that weak again. It is shown in the graphic that the harmonics are faint and low then black and high, after that faint and low in the end.

Subject 2 pronounces 'cause' with frequency -0,5725-0,6358 and time 0,29 second. When he pronounces 'cause', the harmonics of amplitude are weak in the beginning, then strong and weak again. It is shown in the graphic that the harmonics are low and faint in the beginning, then high in the middle and low again.

Subject 3 pronounces 'cause' with frequency -0,9165-1,187 and time 0,36 second. When she pronounces 'cause' the harmonics of amplitude are weak in the beginning, then strong and weak again. It is shown in the graphic that the harmonics are low in the beginning, then high in the middle and low again.

\section{The Pronunciation of 'cause'}

Table 3. The Pronunciation of 'cause' by the three subjects

\begin{tabular}{|c|c|c|}
\hline Word & Subject & Pronunciation \\
\hline What & S1 & $/ \mathrm{kaz} /$ \\
\hline & $\mathrm{S} 2$ & $/ \mathrm{keIs} /$ \\
\hline & $\mathrm{S} 3$ & $/ \mathrm{kos} /$ \\
\hline
\end{tabular}

From the table above, we can know that Subject 1 (S1) pronounces 'cause' with /kaz/, Subject 2 (S2) pronounces /keIs/, and Subject 3 (S3) pronounces /kos/. When S2 pronounces 'cause' with /keIs/, vowel /a/ $\rightarrow /$ eI/ and consonant /z/_/s/, it is influenced by the characteristics of Madurese language that $/ \mathrm{a} /$ is substituted with /eI/ and /Z/ is substituted with /s/. When S3 pronounces 'cause' with 
A Phonological Analysis

/kos/, vowel /a/ $\rightarrow / \mathrm{o} /$ and consonant /z/_/s/, it is influenced by the characteristics of Madurese language that $/ \mathrm{a} /$ is substituted with /o/ and /z/ is substituted with /s/.
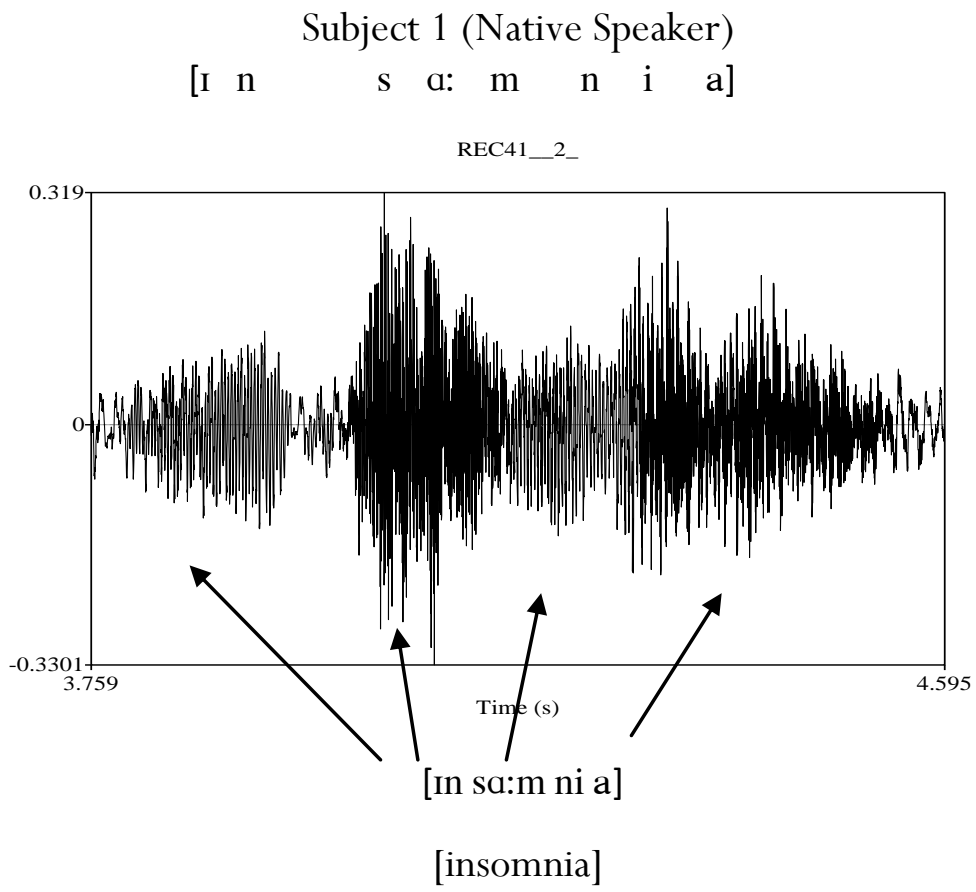

Subject 2 (Madurese English Teacher 1)

$\left[\begin{array}{lllllll}l \mathrm{n} & & \mathrm{s} & \mathrm{o} & \mathrm{m} & \mathrm{n} & \mathrm{i}\end{array}\right.$

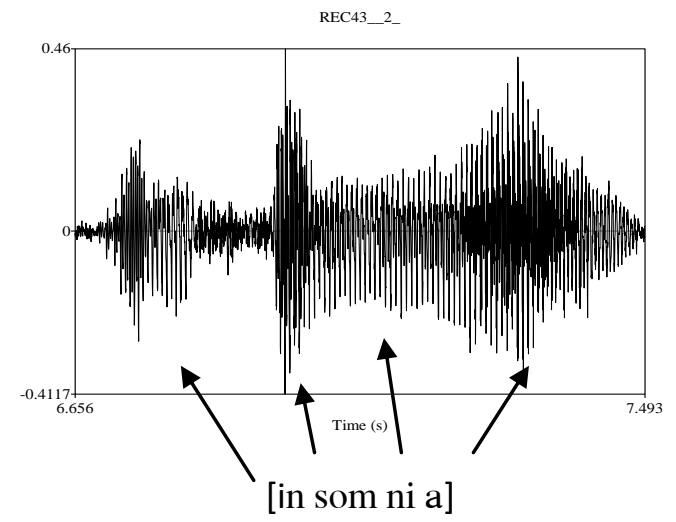

306 Volume 5, Issue 2. December 2016 | IJET 
[insomnia]

Subject 3 (Madurese English Teacher 2)

$\left[\begin{array}{llllllll}1 & \mathrm{n} & \mathrm{s} & \mathrm{o} & \mathrm{m} & \mathrm{n} & \mathrm{i} & \mathrm{a}\end{array}\right]$

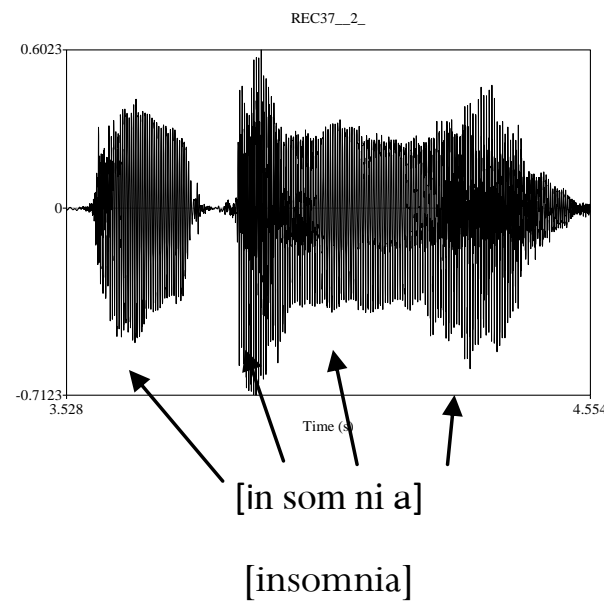

\section{Figure 8. The Comparation of Oscillographic Pronunciation of 'insomnia'}

Based on those three oscillograms above, we can see that subject 1 pronounces 'insomnia' with frequency -0,3301-0,319 and time 8,36 second. When she pronounces 'insomnia' the harmonics of amplitude are weak in the beginning, strong in the middle and followed with weak in the end. It is shown in the graphic that the harmonics are low in the beginning, starts rising, high in the middle then becomes falling and low in the end.

Subject 2 pronounces 'insomnia' with frequency -0,4117-0,46 and time 8,37 second. He pronounces it word by word, while subject 1 does not. When he pronounces 'insomnia', he starts it with /in/ and the harmonics of amplitude are weak in the beginning and then falling, there is a gap, and followed with strong in the middle and then falling again in the middle, then rising and strong in the end. It is shown in the graphic that the harmonics start rising when he pronounces / som/ and the harmonics become strong in the middle, and then falling when he pronounces / ni/ and followed with / a/ that are rising in the end. 
Subject 3 pronounces 'insomnia' with frequency -0,71230,6023 and time 1,026 second. She pronounces it word by word, while subject 1 does not. When she pronounces 'insomnia', she starts it with /in/ and the harmonics of amplitude that are weak in the beginning and then falling and then there is a gap, followed with strong in the middle and then falling again in the middle, then rising in the end. It is shown in the graphic that the harmonics start rising when he pronounces /som/ and the harmonics become strong in the middle and then falling when he pronounces / ni/ and followed with /a/.

In reading the English text, for some words, the oscillographic pronunciation of Subject 2 and Subject 3 when it is compared to subject 1 is slightly different but sometimes it makes different meaning and it does not make different meaning. Besides, their Madurese language characteristics affect in reading the English text. While reading it, they made some sound changes: vowel, consonant and diphthong. Furthermore, they also made deletion and addition.

\section{CONCLUSION}

After conducting this research, it is concluded that the pronunciation of subject 2 and subject 3 are unintelligible because they often make mispronunciation which can make their students do not understand what they say. Therefore, it is recommended that the Madurese English teacher and all English teachers need to improve the pronunciation by practicing to pronounce English words regularly and checking their pronunciation in dictionary, joining conversation club that the trainer is an English native speaker, listening to English conversation from the cassette, radio or television (English program), and continuing their education by choosing English Department or taking an English course. 


\section{REFERENCES}

Brown, HD. (2005). Language Assessment: Principles and Classroom Practices. New York: Pearson.

Crystal, David. (1997). A Dictionary of Linguistics and Phonetics. Oxford: Blackwell Publishers, Ltd.

Francis, W. Nelson. (1958). The Structures of American English. New York: The Ronal Press Company.

International Phonetic Association. (2000). Handbook of the International Phonetic Association. Cambridge :Cambridge University Press.

Jones. (1987). An outline of English phonetics. London: Cambridge University Press.

Kormos, J. (2006). Speech Production and Second Language Acquisition. New Jersey: Lawrence Erlbaum Associates.

Odden, D. (2006). Introducing Phonology. Cambridge: Cambridge University Press.

Pawitra, Adrian. (2008). Kamus Standard Bahasa Madura-Indonesia. Jakarta: Dian Rakyat.

Richards, J., Platt, J., \& Weber, H. (1992). Longman Dictionary of Applied Linguistics. Essex: Longman Group UK.

Robins, RH. (1989). General Linguistics. UK: Longman Group.

Sofyan, Akhmad, dkk. (2008). Tata Bahasa-Bahasa Madura. Sidoarjo: Balai Bahasa Surabaya Departemen Pendidikan Nasional.

Wahyuningrum, Rida. (2006). A Phonological Analysis of English Speech Sounds Produced by Madurese EFL. Unpublished Thesis. Surabaya: Unesa. 